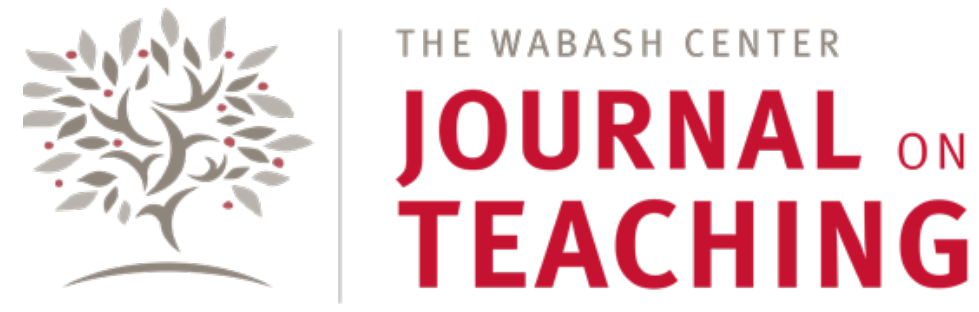

F O R U M

\title{
Remembering Dr. James H. Cone
}

\author{
Isaac Sharp \\ Union Theological Seminary
}

\begin{abstract}
In this essay, I reflect on Dr. James H. Cone's legacy as a teacher and mentor who generously invested in multiple generations of students - including white students like me. This is one of several short essays presented by recent students at a public forum at Union Theological Seminary after his death in 2018.
\end{abstract}

\author{
KEYWORDS \\ James Cone, teaching, mentoring, white students, black theology
}

When I moved to New York City from Atlanta in the fall of 2014, other than my advisor, I knew precisely no one at Union. I was one of only two incoming PhD students that year, and the only other student in my cohort had already completed a degree at Union, which meant that he skipped all of the orientation activities, and that I regularly had to introduce myself as the new PhD student. All of which is to say that, for a while there, I was kind of on my own. But then, before the semester started, I got an email from the first person at Union to personally reach out in order to welcome and get to know me. That person was Dr. James H. Cone.

At first, I thought I was in trouble-honest to God. I could not think of anything that James Cone would want to talk to me about, and imagined that maybe, I don't know, he was going to be the one to deliver the unfortunate news that my admission to the program was a mistake. Much to my relief and surprise, he did no such thing. During that first meeting in his office, Dr. Cone instead told me that he had heard about me, that he was glad I was at Union, that he wanted to know more about my work, and that he would make space in an already full class he was teaching that semester if I wanted to take it. I did, obviously.

The course, "God and Human Suffering," was incredible. All of his courses were. James Cone's lectures were the stuff of legends after all. At least a portion of each and every session in each and every course would be devoted to a sweeping tour of all of the relevant material, always delivered with an existential passion and intensity that instantly communicated one of the abiding truths of his entire life's work: for Dr. Cone, theology was never an abstract game meant for disengaged intellectuals.

Teaching theology wasn't either. In that first course and in every other course that I subsequently took with him, he constantly reminded us that disciple-making should never be the primary purpose of theological education-though his job would have been much easier if it was because many of us would have followed him to the ends of the earth. Dr. Cone's goal as a theology professor was much loftier and far more labor intensive. I know because he told us what it was almost as often as he showed us what it required. His near-weekly refrain, "I want you to find your theological voice," was consistently supported by an ongoing commitment to doing whatever it might take to help his students get there. His particular example was all the more important for those of us aspiring to one day teach theology or religion at the post-secondary level. He certainly helped multiple generations of students find their theological voices, but he also helped some of us learn how to pass that gift on. 
A few semesters and several courses together later, for instance, Dr. Cone sent me another email asking if I could come meet with him again. Though I was sure that, this time, I really was in trouble, he surprised me once more. In what was easily the most humbling experience of my academic career thus far, Dr. Cone asked if I would be willing to serve as one of the teaching fellows for his "Introduction to Systematic Theology" class. I enthusiastically accepted, obviously. During the last semester that he would ever teach that particular course, Dr. Cone gave me the incredible opportunity to practice what he had taught me: that fall, he helped me begin helping his (and my) students find their theological voices.

One of the last times I ever spoke with him came during the spring of 2017 when I was working on my comprehensive exams. By that point, whenever I received emails from Dr. Cone-or from his longtime assistant and invaluable right hand, Vicky Furio-I had finally begun accepting that maybe I wasn't in trouble and that maybe he just needed to check in about something. So, of course, out of all of the times that he called me to his office, this time was the only time that I actually was in trouble. This time, Dr. Cone dutifully informed me that my plan for my comps was simply not going to work and that I absolutely must devote one of my four exams to a study of black evangelicalism. A bit of context here: at Union, doctoral students propose their own agenda for comprehensive exams, and though I had intended to cover the history of black evangelicals in my dissertation on twentieth century U.S. American evangelicalism, that was not enough for Dr. Cone's exacting standards. In retrospect, I'm glad he intervened. That exam became my strongest and most fruitful of all. Not only did I get a dissertation chapter and at least a couple of conference papers out of it, I may have even gotten a book out of it. I certainly wound up with enough material for one.

So, then, what's the point of this reflection? That's a fair question. Because the editors could have invited contributions from a hundred other people with similar stories about Dr. Cone-stories about what it was like to hear him lecture, what it felt like to be invited to meet with him, how it came as a surprise when he was adamant about the need for you to change your plans, and so on. And if there was ever anything that Dr. Cone would not abide, it was the kind of pointless rambling and obfuscation for which he had an unceremonious and technical term that I'll omit to save the editors from needing to redact it. In his honor, though, I will cut to the chase.

The point that I want to make in relaying these stories is this: Dr. James H. Cone, one of the twentieth century's most important Christian theologians, had precisely zero responsibility for investing so heavily in me, a white doctoral student in social ethics, but he did it anyway. I am quite aware that he had better things to do, but he went out of his way to get to know me before anyone else did, to challenge and push me, and to help me learn how to teach. To this day, I remain dumbfounded by the grace of that. Various tributes have rightly emphasized that James H. Cone was the most significant Christian theologian of his generation, which he most certainly was. But if there is anything that I would want readers to know about Dr. Cone, it would be that he was also a teacher who was never too important to keep tabs on and check in with successive generations of masters and doctoral students, many of whom weren't even his own.

I have often heard that, over the years, there have been folks who have gotten the impression that James Cone's classroom was sometimes a tough place for white students - that may indeed have been the case. Honestly, I hope it was the case and often. Because, for those who look like me, it might have been the first time that they were ever challenged in that particular way in a classroom setting. But if there is any truth to that perception, I would argue that the reason for it has more to do with the fact that his classrooms were always so thoroughly suffused with his work-and he made no bones about the fact that he did not write primarily for white Christians - than it did with his personal interactions with white students.

Yes, James Cone's work made it absolutely clear that the price of admission for white Christians wanting to come alongside the black theological struggle for liberation was high. On his terms, it required what I would suggest was a conversion experience involving repentance and a turning away from a Christian faith distorted by the accretions of white-ness. But for those who were wiling to accept those terms, he was more than happy to welcome them into the struggle. Is it his fault that there have been so few?

When it came specifically to his students, however, I would argue that Dr. Cone had far more grace than most people would probably imagine. My story may be just one example, but it also is not. For more than fifty years, he willingly and voluntarily invested in his students-including countless white students-often personally and directly, but never showily or for the sake of praise. If I'm any indication, that investment wasn't reserved for the deserving. If only half of all professors had just a fraction of that level of care for the kinds of students who, on paper, it doesn't make sense for them to do so, academia would be a very different place. 


\section{ADDITIONAL CONTRIBUTIONS TO THE FORUM ON DR. JAMES CONE}

Editor. 2020. "Introduction to the Forum on Dr. James H. Cone as Teacher and Mentor." The Wabash Center Journal on Teaching 1(2): 79-80. https://doi.org/10.31046/wabashcenter.v1i2.1501.

\section{ABOUT THE AUTHOR}

Isaac Sharp recently received his PhD in Social Ethics from Union Theological Seminary, where he currently serves as Program Director for Social Ethics, Community Engagement, and Social Justice. 
